\title{
The role of Helicobacter cinaedi in the development of atherosclerosis
}

Tevhide Ziver Sarp ${ }^{1}$, Safa Gode², Suat Saribas³, Sevgi Ergin³, Gökhan Kasnak, Harika Oyku Dinc ${ }^{3}$, Halit Tokman ${ }^{3}$, Banu Tufan Kocak $^{5}$, Melike Keskin ${ }^{3}$, Hrisi Bahar Tokman ${ }^{3}$, Bekir Kocazeybek ${ }^{* 3}$

'Eastern Mediterranean University, Faculty of Health Sciences, Nutrition and Dietetic Department, Famagusta, North Cyprus via Mersin 10, Turkey

IIstanbul Mehmet Akif Ersoy Thoracic and Cardiovascular Surgery Training and Research Hospital, Department of Cardiovascular Surgery, Istanbul, Turkey

${ }^{3}$ Istanbul University-Cerrahpasa, Cerrahpasa Faculty of Medicine, Department of Medical Microbiology Istanbul University, Istanbul, Turkey ${ }^{4}$ Istanbul University, Faculty of Dentistry, Department of Periodontology, Istanbul, Turkey

${ }^{5}$ T.C. Health Ministry Erenkoy Mental Health and Neurology Training and Research Hospital, Istanbul, Turkey

Abstract

Helicobacter cinaedi (H. cinaedi) is a Gram-negative curved motile rod that causes bloodstream or enteric infections. It was suggested that $H$. cinaedi was involved in the progression of atherosclerosis. We aimed to investigate the presence of $\mathrm{H}$. cinaedi DNA using a nested-polymerase chain reaction (PCR) in atheroma plaques from patients with atherosclerosis-induced vascular diseases. A total of 129 patients diagnosed with valvular heart disease due to atherosclerosis and 146 patients with non-atherosclerotic post-stenotic dilatation were included as the patient and the control groups, respectively. The ATCC BA847 H. cinaedi strain was used as the positive control for the nested-PCR method. We investigated $H$. cinaedi DNA in our study groups using the nested-PCR method and detected only six $H$. cinaedi DNA (4.65\%) in the 129 atherosclerotic patient group. We detected significant difference between patient and control groups with respect to the presence of $\mathrm{H}$. cinaedi on the basis of Fischer's exact test $(p=0.010)$ by univariate analysis. Age (OR: 1.042 , $p=0.016)$, total cholesterol ( $\geq 200 \mathrm{mg} / \mathrm{dL})(O R: 1.849, p=0.0001)$, and high-density lipoprotein $(\geq 50 \mathrm{mg} / \mathrm{dL})(\mathrm{OR}: 0.745, p$ $=0.039$ ) levels were detected as independent variables for the risk of atherosclerosis development in the patient group. The presence of $\boldsymbol{H}$. cinaedi was not detected as an independent variable in a multivariate analysis. Previous studies suggested that $H$. cinaedi-induced oral infections might translocate to vascular tissue and induce chronic inflammation in the aorta, which subsequently may lead to atherosclerotic plaque formation. In conclusion, we could not suggest that there is a causal relationship between $H$. cinaedi and the development of atherosclerosis. However, age (OR: 1.042), total cholesterol ( $\geq 200 \mathrm{mg} / \mathrm{dL}$, OR: 1.849 ), and high-density lipoprotein ( $\geq 50 \mathrm{mg} / \mathrm{dL}$, OR: 0.745 , as protective) levels have a significant role in the pathogenesis of atherosclerosis development. We also suggest that the presence of $H$. cinaedi may contribute to the risk of atherosclerosis development due to the univariate comparison result.

Keywords

Helicobacter cinaedi $\bullet$ atherosclerosis $•$ nested-polymerase chain reaction (PCR)

Received: 18.03.2020, Accepted: 08.12.2020

\section{Introduction}

Helicobacter cinaedi and $H$. fennelliae were initially considered to belong to the genus of Campylobacter, and these Gram-negative curved motile rods in addition to $H$. pylori were reclassified to the genus Helicobacter in 1989 [1]. Animals were speculatively suggested as the source of $H$. cinaedi infections in humans and specifically, $H$. cinaedi strains isolated from dogs and hamsters have the ability to adhere to and invade human intestinal epithelial Caco-2 cells in-vitro $[2,3]$. $H$. cinaedi was isolated from homosexual men with enterocolitis and initially called a Campylobacter-like organism for the first time [4].

$H$. cinaedi is frequently considered to be the causative agent of bloodstream or enteric infections and also has been isolated from cases of cellulitis, sepsis, meningitis, and septic arthritis. Resembling an opportunistic pathogen, $H$. cinaedi causes infections commonly seen in immunocompromised patients (such as human immunodeficiency virus [HIV] patients) or patients undergoing chemotherapy [5].

Recent studies have suggested that inflammatory- and immune-related mechanisms, activated by both noninfectious and infectious agents, may be involved in atherosclerotic plaque development $[6,7]$. The first evidence suggested a link between 
infectious agents and cardiovascular diseases as reported by Saikku et al. [8]. They presented serological evidence of a causal relationship between Chlamydia pneumoniae and coronary atherosclerosis in 70 male patients with myocardial infarction or chronic coronary artery disease. Histopathological and molecular studies have confirmed that $C$. pneumoniae is present within the atherosclerotic plaque [7]. However, $C$. pneumoniae is not the only infectious agent that is thought to play a role in the atherosclerosis development. Similarly, Hajjar et al. [9] suggested that Herpes Simplex virus (HSV-1) may induce lipid accumulation in arterial smooth muscle cells during human atherogenesis, leading to lipid accumulation, which is a characteristic atherosclerotic feature. On the other hand, $H$ pylori has been detected in carotid atherosclerotic lesions and has been shown to be associated with features of inflammatory cell response. $H$. pylori is also thought to be related to atherosclerosis and aneurysm development [10, 11]. Until recently, a certain number of infectious agents have been associated with atherosclerotic lesions: these agents include $H$. pylori, cytomegalovirus (CMV), Epstein-Barr virus (EBV), HIV, HSV-1 and -2, and hepatitis viruses B and C [7]. Recently, $H$. cinaedi infection was thought to be involved in the progression of atherosclerosis, and $H$. cinaedi antigens were detected in atherosclerotic plaques in postmortem human specimens [12], in which they were colocalized with macrophages. These observations strongly suggest that $H$. cinaedi may be involved in the pathogenesis of human atherosclerotic development.

In this case-control study, we aimed to investigate the presence of $H$. cinaedi DNA using a nested-polymerase chain reaction (PCR) in atheroma plaques that were collected from patients with atherosclerosis-induced vascular diseases during cardiovascular surgical procedures for the first time in Turkey.

\section{Materials and Methods}

This case-control study was conducted between November 2016 and June 2018 at the Istanbul MehmetAkif Ersoy Thoracic and Cardiovascular Surgery Training and Research Hospital, Department of Cardiovascular Surgery and also Cerrahpasa Medical Faculty, Department of Medical Microbiology.

Patient Group: A total of 129 patients diagnosed with valvular heart disease due to atherosclerosis based on clinical findings and radio diagnostics, who underwent surgery for carotid, femoral, and coronary artery surgery, were included in the study group. Atheroma plaques were obtained from these patients during surgery. The patient group included 62 patients with carotid artery disease, 47 patients with abdominal aortic aneurysm, 17 patients with ascending aortic aneurysm, and 3 patients with femoral artery disease.
Control Group: A total of 146 patients with advanced aortic valve stenosis due to rheumatic fever or degeneration and with developed non-atherosclerotic post-stenotic dilatation and who had undergone aortic valve replacement were included as the patient control group in this study. Patients with acute infectious diseases, cancer, chronic liver and/or renal disease, or individuals who were seropositive for hepatitis $B$ and $C$ were excluded from this study. This study was approved by the ethics committee of Cerahpasa Medical Faculty (No: 83045809/604.01/02-40899 Date: 09 February 2015), and written informed consent in the study was obtained from all patients. Other clinical characteristics were obtained from clinical records with patient permission.

Collection of tissue specimens: Atheroma plaques were collected from the patient group during cardiovascular surgical procedures. Vascular tissue specimens with nonatherosclerotic post-stenotic dilatation were collected from the control group during cardiovascular surgical procedures. Between 20 and $25 \mathrm{mg}$ from all collected tissue specimens were stored in AllprotectTM Tissue Reagent (Life Technologies, Foster City, CA) and transferred to the Microbiology Laboratory of Cerahpasa Medical Faculty in a cold chain. All of the samples were stored at $-80^{\circ} \mathrm{C}$ until the time of the study.

\section{Culture of Standard Helicobacter cinaedi ATCC strain}

The ATCC BA847 H. cinaedi strain was used as the positive control for the nested-PCR method. This strain was incubated in trypticase soy agar/broth with defibrinated sheep blood for three days at $37^{\circ} \mathrm{C}$ under microaerophilic conditions. There was turbidity in the bottom of trypticase soy broth, and colorless, transparent smooth colonies were observed on solid agar media. DNA isolation of the ATCC BA847 H. cinaedi strain was performed using the High Pure PCR Template Preparation Kit, (Roche Diagnostics $\mathrm{GmbH}$, Manheim, Germany) according to the manufacturer's recommendations.

\section{DNA Extraction from Tissue Specimens}

Tissue specimens were minced using scalpels under sterile conditions. Genomic DNA was purified from 20 to $25 \mathrm{mg}$ of minced tissue using a commercial DNA purification kit (High Pure PCR Template Preparation Kit, Roche Diagnostics $\mathrm{GmbH}$, Mannheim, Germany) according to the manufacturer's instructions and stored at $-80^{\circ} \mathrm{C}$ until further use. 


\section{Nested PCR Method}

$H$. cinaedi-specific primers for the $c d t$ gene region were used for the recovery of DNAs using the nested-PCR method [13]. Primers used in the PCR method are shown in Table 1.

For the PCR assay, a $10 \mu \mathrm{L}$ DNA template was added to a $40 \mu$ reaction mixture consisting of $1 \mu$ l each of the forward and reverse primers (50 pmol/ $\mu \mathrm{l}$ each), $5 \mu \mathrm{l} 10 \mathrm{X}$ Taq buffer with $\mathrm{KCl}, 3 \mu \mathrm{l} 25 \mathrm{mM} \mathrm{MgCl} 2,1 \mu \mathrm{dNTP}$ stock (200 mM each dATP, dTTP, dCTP, and dGTP) (Fermentas ${ }^{\circledR}$, Lithuania), 1.25 $\mathrm{U}$ Taq DNA polymerase (Fermentas ${ }^{\circledR}$, Lithuania), and 28.75 $\mu \mathrm{l}$ of nuclease-free water. Amplification was carried out in a thermal cycler (PTC-100, MJ Research Inc., USA) under the following conditions: (1) initial denaturation for $3 \mathrm{~min}$ at $95^{\circ} \mathrm{C}$; (2) 35 cycles of $1 \mathrm{~min}$ at $98^{\circ} \mathrm{C}$; (3) $30 \mathrm{sec}$ at $58^{\circ} \mathrm{C}$; and (4) $35 \mathrm{sec}$ at $68^{\circ} \mathrm{C}$. The final extension was performed at $68^{\circ} \mathrm{C}$ for $7 \mathrm{~min}$. For the nested PCR assay, $H$. cinaedi nested PCR primers were used. Three microliters of the reaction product were used for the nested PCR procedure (under the same conditions as those described previously). The amplification products were visualized on $1.5 \%$ agarose gel electrophoresis under ultraviolet light. For the exclusion of the PCR inhibitors, all of the samples were tested in a separate run using beta globin primers. Positive specimens were confirmed by DNA sequence analyses.

\section{Statistical Analysis}

The data obtained in this study were analyzed using the SPSS (version 17.00) statistics program. The data were evaluated using the Pearson chi-square and Fisher's exact tests. Fischer's exact test was used to compare frequency and percentages for the patient and control groups and also for two group comparisons. The chi-square test was used to compare $H$. cinaedi presence for the patient and control groups. The gender, age, total cholesterol ( $\geq 200 \mathrm{mg} / \mathrm{dL}$ ), triglyceride $(\geq 150 \mathrm{mg} / \mathrm{dL})$, high-density lipoprotein $(\geq 50 \mathrm{mg} /$ $\mathrm{dL}$ ), low-density lipoprotein ( $\geq 100 \mathrm{mg} / \mathrm{dL}$ ), fasting blood sugar $(\geq 125 \mathrm{mg} / \mathrm{dL}$ ) values, and the $H$. cinaedi presence were included as independent variables in multivariate analysis with logistic regression. The odds ratio (OR) operation was calculated to evaluate the increase in the risk of atherosclerosis development. Significance values were defined as $p<0.05 ; p$ $<0.001$ was considered highly statistically significant.

\section{Results}

A total of 275 cases classified as the study patients were included consisting of 62 patients with carotid artery disease, 47 patients with abdominal aortic aneurysm, 17 patients with ascending aortic aneurysm, 3 patients with femoral artery disease, and 146 controls. The demographic properties of the all-study cases are presented in Table 2. All of the groups were matched in terms of age and gender with recorded demographic data $(p>0.05)$.

We used cutoff values for total cholesterol ( $\geq 200 \mathrm{mg} / \mathrm{dL})$, triglyceride ( $\geq 150 \mathrm{mg} / \mathrm{dL})$, high-density lipoprotein $(\geq 50 \mathrm{mg} /$ $\mathrm{dL}$ ), low-density lipoprotein ( $\geq 100 \mathrm{mg} / \mathrm{dL})$, and fasting blood sugar $(\geq 125 \mathrm{mg} / \mathrm{dL})$ values as higher than normal values of these variables in order to classify the patient and control group cases. We used the above cutoff values of variables, smoking, and the $H$. cinaedi presence for the comparisons of groups and also for the multivariate logistic regression. We detected six $H$. cinaedi DNAs (4.65\%) in the group of 129

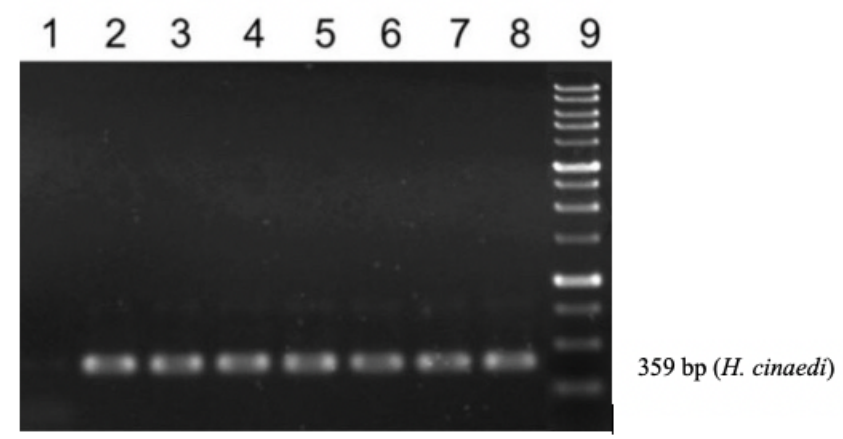

Figure 1. Results of single-step in-house PCR and nested-PCR. Lane 1: Negative control; lane 2: ATCC BA847 H. cinaedi positive control; lane 3-8: positive samples for $H$. cinaedi DNA, $\sim 359 \mathrm{bp}$; lane 9: Size marker 100 bp ladder

Table 1. Primers used in the nested-PCR method [5]

\begin{tabular}{cc}
\hline & Sequences (5'-3') \\
\hline H.cinaedi & 1F: GGA GCT GTG AGT GTG CTG \\
1R: AAA TGA CCG ACA CGA GCT G & 659 bp \\
Hested PCR) & 2F: GGA TTT AGG CTC TCG CTC TCG TCC GGA TAT \\
(neta-globin & F: ACA CAA CTG TGT TCA CTA GC \\
& R: GGAAAA TAG ACC AAT AGG CTG \\
\hline
\end{tabular}


atherosclerotic patients. We detected a significant difference between patient and control groups for total cholesterol $(\geq 200 \mathrm{mg} / \mathrm{dL}$ ), low-density lipoprotein $(\geq 100 \mathrm{mg} / \mathrm{dL}$ ) based on the Pearson Chi-Square (OR $=26.32, p=0.001$ and $\mathrm{OR}=$ $8.49, p=0.004$, respectively) and the presence of $H$. cinaedi based on the Fischer's exact test $(p=0.010)$ (Table 3$)$. Using single-step in-house and nested PCR with the ATCC BA847 $H$. cinaedi strain as a positive control, we detected $H$. cinaedi DNA in six patient tissue specimens out of the 129 patient cases (Figure 1).
The gender, age, total cholesterol ( $\geq 200 \mathrm{mg} / \mathrm{dL}$ ), triglyceride $(\geq 150 \mathrm{mg} / \mathrm{dL}$ ), high-density lipoprotein $(\geq 50 \mathrm{mg} / \mathrm{dL})$, lowdensity lipoprotein $(\geq 100 \mathrm{mg} / \mathrm{dL}$ ), fasting blood sugar ( $\geq 125$ $\mathrm{mg} / \mathrm{dL}$ ) values and the $H$. cinaedi presence were included as independent variables in multivariate logistic regression. Age (OR:1.042, $p=0.016$ ), total cholesterol ( $\geq 200 \mathrm{mg} / \mathrm{dL}$ ) (OR: $1.849, p=0.0001)$, and high-density lipoprotein ( $\geq 50 \mathrm{mg} / \mathrm{dL}$ ) (OR: $0.745, p=0.039$ ) levels were detected as independent variables for the risk of atherosclerosis development in the patient group (Table 4).

Table 2. The demographical characteristics of the patient and control groups

\begin{tabular}{|c|c|c|c|}
\hline Variables & $\begin{array}{l}\text { Patient Group } \\
\quad(n: 129)\end{array}$ & $\begin{array}{l}\text { Control Group } \\
\text { (n: 146) }\end{array}$ & $p$ \\
\hline Age (mean \pm SD) & $61.24 \pm 8.345$ & $63.55 \pm 7.92$ & $>0.05$ \\
\hline \multicolumn{4}{|c|}{36 (24.7\%) } \\
\hline Gender & 94 (72.9\%) & 110 (75.3\%) & $>0.05$ \\
\hline Yes & 50 (38.8\%) & 53 (36.3\%) & $>0.05$ \\
\hline \multicolumn{3}{|l|}{ Smoking } & $>0.05$ \\
\hline Total Cholesterol (mg/dL) & $194.63 \pm 53.71$ & $220.54 \pm 47$ & 0.0001 \\
\hline Triglyceride (mg/dL) & $142.38 \pm 106.59$ & $148.29 \pm 110.03$ & 0.651 \\
\hline High-density lipoprotein (mg/dL) & $51.06 \pm 17.44$ & $47.95 \pm 18.16$ & 0.149 \\
\hline Low-density lipoprotein (mg/dL) & $112.14 \pm 40.24$ & $130.23 \pm 42.05$ & 0.0001 \\
\hline Fasting blood sugar (mg/dL) & $107.49 \pm 23.49$ & $107.74 \pm 27.09$ & 0.936 \\
\hline H. cinaedi & $6(4.65 \%)$ & $0(0 \%)$ & 0.010 \\
\hline
\end{tabular}

Table 3. Comparison of patient and control groups for various variables

\begin{tabular}{|c|c|c|c|c|c|c|c|}
\hline \multirow[b]{2}{*}{ Variables } & \multirow[b]{2}{*}{ Patient Group } & \multirow[b]{2}{*}{ Control Group } & \multirow[b]{2}{*}{$x^{2}$} & \multirow[b]{2}{*}{$p$} & \multirow[b]{2}{*}{ OR } & \multicolumn{2}{|c|}{$\% 95 \mathrm{Cl}$} \\
\hline & & & & & & Min & $\operatorname{Max}$ \\
\hline Smoking & 50 & 53 & 0.177 & 0.674 & 1.11 & 0.681 & 1.811 \\
\hline $\begin{array}{l}\text { Total }^{*} \text { Cholesterol } \\
(\geq 200 \mathrm{mg} / \mathrm{dL})\end{array}$ & 96 & 64 & 26.32 & 0.001 & 3.727 & 2.231 & 6.226 \\
\hline $\begin{array}{l}\text { Triglyceride* } \\
(\geq 150 \mathrm{mg} / \mathrm{dL})\end{array}$ & 41 & 22 & 0.296 & 0.587 & 1.154 & 0.689 & 1.932 \\
\hline $\begin{array}{l}\text { High-density* lipoprotein } \\
(\geq 50 \mathrm{mg} / \mathrm{dL})\end{array}$ & 80 & 103 & 2.240 & 0.135 & 0.682 & 0.412 & 1.127 \\
\hline $\begin{array}{l}\text { Low-density* lipoprotein } \\
(\geq 100 \mathrm{mg} / \mathrm{dL})\end{array}$ & 102 & 92 & 8.497 & 0.004 & 2.217 & 1.291 & 3.809 \\
\hline $\begin{array}{l}\text { Fasting blood }{ }^{*} \text { sugar } \\
\quad(\geq 125 \mathrm{mg} / \mathrm{dL})\end{array}$ & 20 & 29 & 0.889 & 0.346 & 0.740 & 0.396 & 1.385 \\
\hline H. cinaedi presence ${ }^{\star *}$ & 6 & 0 & - & 0.010 & - & 0.401 & 0.521 \\
\hline
\end{tabular}

${ }^{*}$ Pearson Chi-Square was applied, **Fisher's Exact Test was applied. 
Table 4. Results of logistic regressions according to the variables in the patient group

\begin{tabular}{|c|c|c|c|c|c|c|c|c|}
\hline & \multirow[b]{2}{*}{ B } & \multirow[b]{2}{*}{ S.E. } & \multirow{2}{*}{ Wald } & \multirow[b]{2}{*}{ df } & \multirow[b]{2}{*}{ Sig. } & \multirow[b]{2}{*}{ OR } & \multicolumn{2}{|c|}{ 95\% C.I. } \\
\hline & & & & & & & Lower & Upper \\
\hline Age & 0.041 & 0.017 & 5.753 & 1 & 0.016 & 1.042 & 1.008 & 1.078 \\
\hline Gender (male) & 0.001 & 0.153 & 0.000 & 1 & 0.997 & 1.001 & 0.742 & 1.349 \\
\hline $\begin{array}{l}\text { Total Cholesterol } \\
(\geq 200 \mathrm{mg} / \mathrm{dL})\end{array}$ & 0.615 & 0.151 & 16.470 & 1 & 0.000 & 1.849 & 1.374 & 2.488 \\
\hline $\begin{array}{l}\text { Triglyceride } \\
(\geq 150 \mathrm{mg} / \mathrm{dL})\end{array}$ & 0.071 & 0.147 & 0.230 & 1 & 0.632 & 1.073 & 0.804 & 1.432 \\
\hline $\begin{array}{l}\text { High-density lipoprotein } \\
\qquad(\geq 50 \mathrm{mg} / \mathrm{dL})\end{array}$ & -0.295 & 0.143 & 4.273 & 1 & 0.039 & 0.745 & 0.563 & 0.985 \\
\hline $\begin{array}{l}\text { Low-density lipoprotein } \\
\quad(\geq 100 \mathrm{mg} / \mathrm{dL})\end{array}$ & 0.193 & 0.165 & 1.371 & 1 & 0.242 & 1.213 & 0.878 & 1.676 \\
\hline $\begin{array}{l}\text { Fasting Blood Sugar } \\
\qquad(\geq 125 \mathrm{mg} / \mathrm{dL})\end{array}$ & -0.160 & 0.176 & 0.831 & 1 & 0.362 & 0.852 & 0.604 & 1.202 \\
\hline H. cinaedi presence & 10.769 & 7720.80 & 0.000 & 1 & 0.999 & 47527 & 0.000 & \\
\hline Constant & 7.824 & 7720.80 & 0.000 & 1 & 0.999 & 2499.6 & & \\
\hline
\end{tabular}

B, beta regression coefficient; S.E., standart error; Wald, test statistics used for the determination of the meaning of variables; d.f., degrees of freedom; Sig, significance; C.I., confidence interval; OR, odds ratio.

\section{Discussion}

The development of atherosclerosis is very complex and includes genetic factors. To the best our knowledge, inflammatory cells have significant roles throughout atherosclerosis pathogenesis, and atherosclerosis is currently accepted as a chronic inflammatory disease leading to cardiovascular disease. When we looked at the pathogenesis of atherosclerosis from an inflammatory perspective, we observed that atherosclerosis-related inflammation is mediated by the main actors of the immune system, such as proinflammatory cytokines, inflammatory signaling pathways, bioactive lipids, and adhesion molecules [14]. Formation of atherogenesis starts with the recruitment of pro-inflammatory monocytes to the intimal layer of the arteries. Monocytes then transform into macrophages. Macrophages take up lipoproteins, leading to the formation of foam cells [15]. These lipid-including macrophages secrete pro-inflammatory mediators that facilitate the necrotic core formation of an atherosclerotic plaque, thus increasing its vulnerability [16].
H. cinaedi-associated atherosclerosis or cardiovascular disease is discussed in a very limited number of studies in the literature, and we could not find any case-control studies among these very limited studies. More specifically, no study involving $H$. cinaedi-associated atherosclerosis has been done in Turkey to the best of our knowledge. For the aforementioned reasons, we selected a patient group including 129 patients with cardiovascular diseases, probably caused by atherosclerosis, and another set of 146 non-atherosclerotic patients as our control group. To investigate the causal relationship between $H$. cinaedi and atherosclerosis development, we investigated whether $H$. cinaedi DNA was absent or present in our study groups using the nested-PCR method. We finally detected six $H$. cinaedi DNAs out of the 129 atherosclerotic cases and the difference between the study and control groups was significant by the univariate analysis $(p=0.010)$. However, we also detected a significant difference between patient and control groups for total cholesterol ( $\geq 200 \mathrm{mg} / \mathrm{dL}$ ) and low-density lipoprotein ( $\geq 100 \mathrm{mg} / \mathrm{dL}$ ) based on the Pearson chi-square test $(O R=26.32)$ and $(O R=8.49)$ respectively. Age (OR: 1.042, total cholesterol ( $\geq 200 \mathrm{mg} / \mathrm{dL}$, OR: 1.849), and high-density lipoprotein ( $\geq 50 \mathrm{mg} / \mathrm{dL}$, OR: 0.745 ) were 
detected as independent variables but not the presence of $H$. cinaedi for the risk of atherosclerosis development in the patient group. There was no case-control study to compare with our results, and therefore we were not able to compare our results with those of other studies.

$H$. cinaedi causes enteric or bloodstream infections in humans, but the route of $H$. cinaedi infection is not clear and is often thought to occur via the fecal-oral route. The suggestion that $H$. cinaedi colonizes the gastrointestinal tract is plausible, and bacterial translocation may lead to bacteremia after mucosal damage $[17,18]$. The mechanism behind this translocation was explained by the invasive nature of $H$. cinaedi. Consequently, $H$. cinaedi invades the peripheral vascular system of the gastrointestinal tract, and may then induce bacterial translocation to the systemic circulation resulting in bacteremia [19].

A myopericarditis case caused by $H$. cinaedi in the literature was first reported by Lewis et al. [20] in 2007. In the study of Khan et al., [12] in which a possible association between $\mathrm{H}$. cinaedi with atrial arrhythmias and atherosclerosis was suggested, patients with atrial arrhythmia had higher concentrations of anti-H. cinaedi IgG antibodies than patients who had undergone coronary angiography for evaluation of ischemic heart diseases. They also detected $H$. cinaedi antigens inside CD68+ macrophages of nine post-mortem atherosclerotic tissues using immunohistochemistry. These findings provided the first evidence for the association of $H$. cinaedi and cardiovascular diseases. Khan et al. [21] suggested a causal relationship between $H$. cinaedi and atherosclerosis development. They designed an experimental model with mice. Their study was the first to find that $H$. cinaedi infection induced the development of atherosclerosis in hyperlipidemic mice. Therefore, they suggested that $H$. cinaedi invasion of the vasculature increases expression of proinflammatory genes, accumulation of neutrophils, and induction of macrophage-derived foam cell formation and eventually enhances atherosclerosis development. Since it was suggested that $H$. cinaedi is involved in arteriosclerosis development, the thought that $H$. cinaedi may also play a role in infective abdominal aortic aneurysms has also been confirmed by the following case reports. In one of these case reports, $H$. cinaedi was isolated by blood culture in a patient with abdominal aortic aneurysm by Unosawa et al. [22]. Similarly, Nishida et al. [23] reported a patient with an $H$. cinaedi infected abdominal aortic aneurysm.

Recently, D'elios et al. [24] identified a $200 \mathrm{kDa}$ Cinaedi Atherosclerosis Inflammatory Protein (CAIP) in $\mathrm{H}$. cinaedi strains, and they claimed that at least $27 \%$ of $H$. cinaediinfected individuals with atherosclerosis had CAIP-specific antibodies. They also suggested that atheromatous plaques of atherosclerotic patients had increased CAIP-specific T cells. They also suggested that CAIP may induce differentiation and maintenance of the pro-inflammatory profile of human macrophages and trigger the formation of foam cells, which form the most prominent atherosclerosis signature. Their results also suggested that CAIP may contribute to the atherosclerosis pathogenesis associated with $H$. cinaedi infection. $H$. cinaedi has the capability for vascular invasion, possibly by bacterial translocation from the intestinal tract to the vascular system as seen in bacteremia. More importantly, $H$. cinaedi antigens were detected in atherosclerotic plaques inside the macrophages [12]. This study strengthened the causal relationship between $H$. cinaedi infection and atherosclerosis. In addition, Khan et al. [21] orally infected Apoeshl mice with $H$. cinaedi and after eight weeks; their experimentally infected mice, rather than uninfected control mice, developed atherosclerosis in their aortas. Given their results, they concluded that $H$. cinaedi may have been involved in atherosclerosis formation.

As the host's chronic inflammatory response is regarded as the most important mechanism for atherosclerosis development [25, 26], Khan et al. [21] observed a significant increase in the expression of inducible nitric oxide synthase, interleukin-1, and toll-like receptor 4 genes in the aortic tissues of their infected mice. The accumulation of lipids in macrophages (foam cell formation) appears to be essential for atherosclerosis development, and $H$. cinaedi may specifically induce foam cell formation. They also showed $H$. cinaedi DNA and RNA in the aorta of infected mice [21]. As a limitation, we could not find any ELISA kit for the detection of antibodies against $H$. cinaedi in our country's market. Therefore, it was not possible to compare PCR results with the serology of our group individuals. These findings of the aforementioned studies suggest that $H$. cinaedi-induced oral infections might translocate to vascular tissue and induce chronic inflammation in the aorta, which subsequently may lead to atherosclerotic plaque formation.

In conclusion, we detected a significant difference between patient and control groups for the presence of $H$. cinaedi DNA using a univariate analysis, but the presence of $H$. cinaedi was not detected as an independent variable in the multivariate analysis. Age, (OR: 1.042), total cholesterol $(\geq 200 \mathrm{mg} / \mathrm{dL}$ ) (OR: 1.849$)$, and high-density lipoprotein $(\geq 50$ $\mathrm{mg} / \mathrm{dL}$ ) (OR: 0.745) levels were detected as independent variables for the risk of atherosclerosis development in the patient group. High-density lipoprotein $(\geq 50 \mathrm{mg} / \mathrm{dL}$ ) (OR: 0.745 ) variable was also suggested as protective in the patient group. There are six case reports to date but no casecontrol studies. Therefore, we could not suggest that there is a causal relationship between $\mathrm{H}$. cinaedi and atherosclerosis development, because the development of atherosclerosis could not be established based on a single factor; it is multifactorial and includes genetic factors. On the other hand, as expected, total cholesterol ( $\geq 200 \mathrm{mg} / \mathrm{dL}$ ), and high-density 
lipoprotein ( $\geq 50 \mathrm{mg} / \mathrm{dL}$, as protective) levels have a significant role in the pathogenesis of atherosclerosis development. We also suggest that the presence of $H$. cinaedi may contribute to the risk of atherosclerosis development as evidenced by our univariate comparison result. However, new serial studies with more cases, especially those infected with $H$. cinaedi, are needed in order to explore such a causal relationship between $H$. cinaedi infection and atherosclerosis development.

\section{Authors' Contributions}

T.Z.S.: Research concept and design, carrying out the experiments, drafting the article or revising it critically for important intellectual content, writing the manuscript; S.G.: Acquisition of data; S.S.: Drafting the article or revising it critically for important intellectual content; S.E.: Analysis and interpretation of data; G.K.: Acquisition of data; H.O.D.: Carrying out the experiments, acquisition of data; H.T.: Literature review; B.T.K.: Analysis and interpretation of data; M.K.: Carrying out the experiments, acquisition of data; H.B.T.: Designing the figures; B.K.: Research concept and design, supervising the project, final proofreading and approval of the version for publication.

\section{Funding}

This study received support from the Research Fund of Istanbul University, under Project No: 3747 . We thank them for their support.

\section{Conflict of Interest}

The authors have no potential conflicts of interest to declare.

\section{Ethics Approval}

This study was approved by the ethics committee of Cerahpasa Medical Faculty (No: 83045809/604.01/02-40899 Date: 09 February 2015) and written informed consent in the study was obtained from all patients.

\section{Additional Information}

This study was presented as oral presentation in 2nd International Human Microbiota: In Health and Diseases Congress, p. 40-41, April 18-22 2018, Antalya, Turkey.

\section{References}

[1] Goodwin C.S., Armstrong J.A., Chilvers T., Peters M., Collins M.D., Sly L., McConnell W., Harper W.E.: Transfer of Campylobacter pylori and Campylobacter mustelae to Helicobacter gen. nov., as Helicobacter pylori comb. nov. and Helicobacter mustelae comb. nov., respectively. Int. J. Syst. Bacteriol., 1989; 39: 397-405

[2] De Witte C., Schulz C., Smet A., Malfertheiner P., Haesebrouck F.: Other Helicobacters and gastric microbiota. Helicobacter, 2016; 21: 62-68

[3] Taniguchi T., Yamazaki W., Saeki Y., Takajo I., Okayama A., Hayashi T., Misawa N.: The pathogenic potential of Helicobacter cinaedi isolated from non-human sources: Adherence, invasion and translocation ability in polarized intestinal epithelial Caco-2 cells in vitro. J. Vet. Med. Sci., 2016; 78: 627-632

[4] Nakamura I., Ohkusu K., Nakagami Y., Tachibana M., Matsumoto T.: First case report of bacteremia due to 'Campylobacter-like organism 3'. Int. J. Infect. Dis., 2016; 42: 51-53

[5] Uwamino Y., Muranaka K., Hase R., Otsuka Y., Hosokawa N.: Clinical features of community acquired Helicobacter cinaedi bacteremia. Helicobacter, 2016; 21: 24-28

[6] Epstein S.E.: The multiple mechanisms by which infection may contribute to atherosclerosis development and course. Circ. Res., 2002; 90: 2-4

[7] Michelsen K.S., Doherty T.M., Shah P.K., Arditi M.: TLR signaling: An emerging bridge from innate immunity to atherogenesis. J. Immunol., 2004; 173: 5901-5907

[8] Saikku P., Leinonen M., Mattila K., Ekman M.R., Nieminen M.S., Mäkelä P.H., Huttunen J.K., Valtonen V.: Serological evidence of an association of a novel Chlamydia, TWAR, with chronic coronary heart disease and acute myocardial infarction. Lancet, 1988; 2 : 983-986

[9] Hajjar D.P., Pomerantz K.B., Falcone D.J., Weksler B.B., Grant A.J.: Herpes simplex virus infection in human arterial cells: Implications in arteriosclerosis. J. Clin. Invest., 1987; 80: 1317-1321

[10] Ameriso S.F., Fridman E.A., Leiguarda R.C., Sevlever G.E.: Detection of Helicobacter pylori in human carotid atherosclerotic plaques. Stroke, 2001; 32: 385-391

[11] Ziver T., Yuksel P., Ipek G., Yekeler I., Bayramoglu Z., Tireli E, Saribas S., Aslan M., Yalvac S.D., Ozdomanic I., et al.: Aneurysm and Helicobacter pylori relationship: The seropositivity of CagA, VacA and other antigens of Helicobacter pylori in abdominal and ascending aortic aneurysms. New Microbiol., 2010; 33: 233-242

[12] Khan S., Okamoto T., Enomoto K., Sakashita N., Oyama K., Fujii S., Sawa T., Takeya M., Ogawa H., Yamabe H., Akaike T.: Potential association of Helicobacter cinaedi with atrial arrhythmias and atherosclerosis. Microbiol. Immunol., 2012; 56: 145-154

[13] Oyama K., Khan S., Okamoto T., Fujii S., Ono K., Matsunaga T., Yoshitake J., Sawa T., Tomida J., Kawamura Y., Akaike T.: Identification of and screening for human Helicobacter cinaedi infections and carriers via nested PCR. J. Clin. Microbiol., 2012; 50 : 3893-3900 
[14] Zhu Y., Xian X., Wang Z., Bi Y., Chen Q., Han X., Tang D., Chen $R$.: Research progress on the relationship between atherosclerosis and inflammation. Biomolecules, 2018; 8: 80

[15] Libby P., Ridker P.M., Hansson G.K.: Progress and challenges in translating the biology of atherosclerosis. Nature, 2011; 473: 317325

[16] Gibson M.S., Domingues N., Vieira O.V.: Lipid and non-lipid factors affecting macrophage dysfunction and inflammation in atherosclerosis. Front. Physiol., 2018; 9: 654

[17] Araoka H., Baba M., Kimura M., Abe M., Inagawa H., Yoneyama A.: Clinical characteristics of bacteremia caused by Helicobacter cinaedi and time required for blood cultures to become positive. J. Clin. Microbiol., 2014; 52: 1519-1522

[18] Nakao S., Hagiya H., Kimura K., Mitsui T., Oyama A., Hongyo K., Takahashi Y., Nakagami F., Tomono K., Rakugi H.: Helicobacter cinaedi-associated carotid arteritis. Acta Med. Okayama, 2018; 72: 189-192

[19] Kawamura Y., Tomida J., Morita Y., Fujii S., Okamoto T., Akaike T.: Clinical and bacteriological characteristics of Helicobacter cinaedi infection. J. Infect. Chemother., 2014; 20: 517-526

[20] Lewis G.D., Holmes C.B., Holmvang G., Butterton J.R.: Case records of the Massachusetss General Hospital. Case 8-2007. A 48-year-old man with chest pain followed by cardiac arrest. $\mathrm{N}$. Engl. J. Med., 2007; 356: 1153-1162
[21] Khan S., Rahman H.N., Okamoto T., Matsunaga T., Fujiwara Y., Sawa T., Yoshitake J., Ono K., Ahmed K.A., Rahaman M.M., et al.: Promotion of atherosclerosis by Helicobacter cinaedi infection that involves macrophage-driven proinflammatory responses. Sci. Rep., 2014; 4: 4680

[22] Unosawa S., Niino T.: An infected abdominal aortic aneurysm caused by Helicobacter cinaedi. Ann. Vasc. Dis., 2015; 8: 318-320

[23] Nishidai K., Iwasawa T., Tamura A., Lefor A.T.: Infected abdominal aortic aneurysm with Helicobacter cinaedi. Case Rep. Surg., 2016, 2016: 1396568

[24] D'Elios M.M., Vallese F., Capitani N., Benagiano M., Bernardini M.L., Rossi M., Rossi G.P., Ferrari M., Baldari C.T., Zanotti G., et al.: The Helicobacter cinaedi antigen CAIP participates in atherosclerotic inflammation by promoting the differentiation of macrophages in foam cells. Sci. Rep., 2017; 7: 40515

[25] Libby P., Ridker P.M., Hansson G.K., Leducq Transatlantic Network on Atherothrombosis: Inflammation in atherosclerosis: From pathophysiology to practice. J. Am. Coll. Cardiol., 2009; 54: 21292138

[26] Tabas I.: Macrophage death and defective inflammation resolution in atherosclerosis. Nat. Rev. Immunol., 2010; 10: 36-46 